\section{Impact of surface acting and deep acting techniques on teachers' organizational commitment}

Impact of surface acting and deep acting techniques

Kazeem Olanrewaju Ogunsola and

Rodrique Ancelot Harvey Fontaine

Department of Business Administration, International Islamic University Malaysia Kulliyyah of Economics and Management Sciences, Kuala Lumpur, Malaysia, and

\author{
Muhammad Tahir Jan
}

Department of Marketing, International Islamic University Malaysia Kulliyyah of Economics and Management Sciences, Kuala Lumpur, Malaysia

\begin{abstract}
Purpose - This paper aims to examine the relationship between surface acting (SA), deep acting (DA) and organizational commitment (OC).

Design/methodology/approach - Guided by affective events theory, the study adapted emotional labour scale and three components model to profile 373 teachers from 30 schools around Peninsular Malaysia. A list-based simple random sampling technique was used to select respondents. Structural equation modeling (SEM) was used to test hypotheses, and the proposed model was assessed through renowned fit indices.

Findings - OC was hypothesized as a second-order construct. SEM result indicates that both SA and DA have significant negative relationship with OC. Fit indices of the hypothesized model showed $\chi^{2} / d f$ ratio $(560.069 / 265)=2.113$, RMSEA (0.055), and CFI (0.936). This result provides empirical support for the data collected.

Research limitations/implications - The study provides new insight on the ongoing debate about SA and DA. Therefore, it advances body of research in this regard. The implication for HR managers is that strategic polices can be institutionalized to buffer the consequences of SA and DA. This is due to the fact that SA and DA may not be abolished for service employees like teachers. The practical implication for teachers is the understanding that emotional regulation process is inevitable because teaching is profoundly an emotional activity job. Besides being a cross-sectional study, the sampled population may have limited the study's outcomes.

Originality/value - Given existing inconsistent results on the consequences of SA and DA, this study shows that not only SA can lead to negative after-effects, DA can also cause the same. Future study can explore spiritual intelligence to examine how best SA and DA can be performed at reduced consequences on $\mathrm{OC}$.
\end{abstract}

Keywords Malaysia, Teachers, Organizational commitment, Deep acting (DC), Surface acting (SA), Emotional labour (EL)

Paper type Research paper

(C) Kazeem Olanrewaju Ogunsola, Rodrique Ancelot Harvey Fontaine and Muhammad Tahir Jan. Published in PSU Research Review. Published by Emerald Publishing Limited. This article is published under the Creative Commons Attribution (CC BY 4.0) licence. Anyone may reproduce, distribute, translate and create derivative works of this article (for both commercial and noncommercial purposes), subject to full attribution to the original publication and authors. The full terms of this licence may be seen at http://creativecommons.org/licences/by/4.0/legalcode
Received 5 October 2019 Revised 8 January 2020 Accepted 11 January 2020 


\section{PRR}

4,1

\section{Introduction}

Supposedly, teachers are saddled with multiple roles, ranging from being a mentor, colleague, friend or supervisor. Kulshrestha and Singhal (2017) assent that teachers' role includes integration and application of knowledge. However, based on affective events theory (AET), researchers posit that some factors are within the work environment that can diminish these functions. Weiss and Cropanzano (1996, p. 12) note that AET "focuses on the structure, causes and consequences of affective experiences" in the workplace. Therefore, the theory identifies factors that can cause different employees' emotional reactions on the job and how these reactions affect the employees.

Researchers (Lam and Chen, 2012; Wegge et al., 2006) submit that AET is based on some assumptions. Firstly, it recognizes the distinct role of emotions in relation to employees' organizational behaviour. Secondly, it proposes that emotional episodes are responses to series of emotional experiences triggered by work events. Thirdly, it theorizes that both current emotions along with emotional history surrounding a work environment affect job commitment. Fourthly, it asserts that, as emotions fluctuate, so does commitment. Lastly, the theory posits that emotions are sometimes incompatible with behaviours required to do a job.

In this regard, Ashkanasy and Humphrey (2011) view emotional labour as one of such factors that can trigger employees' emotional reactions to a number of performance variables such as organizational citizenship behaviour, organizational commitment (OC), intentions to quit, workplace deviance and absenteeism. This provides possible expectations that teachers can be vulnerable to psychological (emotion) and physiological (physical) experiences as a result of EL (Yin et al., 2017; Gökyer, 2018). Hochschild (1983) notes that SA and DA are two techniques of EL. Previous studies indicate that these techniques can have negative impacts on employees' wellness (Indregard et al., 2018). Hence, they are likely to weaken OC.

Against this backdrop, Letendre and Wiseman (2015) proposed the need to understand teachers' emotional experiences and how these experiences impact their organizational functions. Most studies on SA and DA techniques were conducted among health professionals (Indregard et al., 2018; Lartey et al., 2019), tourism and hospitality workers (Prentice, 2014), front-desk service employees (Sonar and Paliwal, 2018; Walsh et al., 2019) and security personnel (Van Gelderen, 2013). Except in Lee and Van Vlack (2017), little is known about how SA and DA determine teachers' OC based on their emotional experiences. This study focuses on Malaysian teachers and intends to adopt a quantitative approach. Previous studies that examined teachers' emotional experiences mostly used qualitative approach (Zembylas, 2003; Dunbar and Baker, 2014) or are conducted outside Malaysia (Hagenauer and Volet, 2014; Mazer et al., 2014). To this end, this study advances body of knowledge theoretically, methodologically and contextually.

\section{Literature}

\section{Emotional labour}

Emotions are spontaneous, crucial and undeniable (Prentice, 2014). However, for positive organizational reasons (Richard and Converse, 2016), some forms of emotions may not be expressible in the workplace (Grandey and Sayre, 2019). Hence, there was the emergence of the EL concept three decades ago. EL is "the process of managing feelings and expressions to fulfil the emotional requirements of a job, such that displayed emotion will enhance expected performance" (Hochschild, 1983, p. 7). It is presumed that allowing emotional liberty may hamper organizational activities (Yin et al., 2017) or lead to irrationality (Verhoef and Terblanche, 2015). So, EL process is usually designed to regulate employees' emotions, 
behaviours, thoughts and actions to conform with organizational desired emotions (Christoforou and Ashforth, 2015; Huys and Renz, 2017; Pillay et al., 2019).

Emotions are categorized into six basic types, e.g. anger, fear, joy, love, sadness and surprise (Greenberg and Baron, 2008). However, teachers are mostly required to engage in positive emotions like joy and love (Trigwell, 2012). Given this expectation, teachers may sometimes experience emotional harmony. This is when they actually feel the emotions required by the job (Addison, 2017). In this same vein, they may experience emotional discord. This is when job expected feelings are incongruent with self-feelings (Indregard et al., 2018; Kwak et al., 2018).

Hochschild (1983, p. 90) argues that when priority is given to organizational desired emotions, "display is what is sold". Impliedly, emotions become commercialized in return for wages, profit, good customer experiences, and so forth (Diefendorff et al., 2011; Grandey and Sayre, 2019). Consequently, employees become liable for their "behavioural expectations on which emotions ought to be expressed and which ought to be hidden" Rafaeli and Sutton (1987, p. 27). This is particularly true for teachers who are required to follow certain norms in the discharge of their responsibilities (Lee and Van Vlack, 2017). The two techniques seemingly used in this regard are discussed below.

\section{Surface acting}

Surface acting (SA) means "the body, not the soul, is the main tool of trade" (Hochschild, 1983, p. 37). It occurs when teachers only alter their emotional expression to correspond with normative patterns, by faking an emotion they do not really feel (Grandey et al., 2013; Addison, 2017). By inference, only outward behavioural expressions require modification while genuine feelings remain intact (Benita et al., 2016; Walsh et al., 2019). Some studies likened SA to façade acting (Andrews et al., 2016) or deliberative dissonance (Zapf, 2002). Deliberative dissonance "is the ability to maintain emotional display even when experienced emotions are different” (Zapf, 2002, p. 246). For instance, an expression of pleasantry by teachers may not necessarily mean happiness or joy, but just acting out to conform with organizational display rules.

\section{Deep acting}

Deep acting (DA) is a form of "real feelings that has been self-induced" (Hochschild, 1983, p. 35). DA relates to "changing one's feelings regarding an interaction so that emotional expressions naturally fall in line with expectations" (Grandey et al., 2013, p. 207). So, rather than mere faking unfelt feelings, individuals actively alter inner feelings to express the emotion they wish to display or that is required by a job (Mann and Cowburn, 2005). To accomplish this, Ashforth and Humphrey (1993) posit that employees need to put effort to stimulate memories, images or thoughts to feel or suppress specific emotions at the workplace. By doing so, they will be able to feel, think and act organizationally desired emotions (Schirmer and Adolphs, 2017). For instance, teachers may induce pleasant memories to alter feelings of irritating in the course of teaching. Within this process, they would have re-defined any disturbing situation.

\section{Dysfunctional aspects of surface acting and deep acting}

Both techniques offer possibility of certain outward appearances which portray teachers positively. In spite of their benefits, existing studies suggest that the techniques can have some negative consequences. These include the following: 


\section{PRR}

4,1

\section{Health consequences}

SA and DA are known to alter expressive behaviours (outward emotions), but most times, not the inner self (Grandey et al., 2015). So, the techniques often result in emotive dissonance (Richard and Converse, 2016). Emotive dissonance comprises feelings of unease which are due to "persistent structural discrepancy between displayed emotions and what is felt" (Yagil, 2015, p. 158).

Researchers argue that faking (SA) or inducing (DA) unfelt feelings commonly lead to self-denial, poor self-esteem or estrangement from self (Dunbar and Baker, 2014; Yin et al, 2017). These experiences are health-risk-related problems which can cause depression, exhaustion and mental distress in employees (Indregard et al., 2018). Other studies mentioned that these forms of emotional denial can cause certain "pernicious psychological effects" (Ashforth and Humphrey, 1993, p. 89) which are detrimental to well-being (Kim and Han, 2009).

Gross (2002) notes that any persistent experience of emotional discrepancy can increase the chance of physical-health-related problems, such as headache, sleeplessness and cardiovascular problems. Others argue that employees may be susceptible to emotional exhaustion (Yilmaz et al., 2015), particularly, when they are psychologically and physically depleted (Mishra and Kumar, 2016).

\section{Performance consequences}

When employees are depleted psychologically and physically, continuous acting can become counter-productive (Kinman et al., 2011). So, rather than SA and DA facilitating task performance, redundancy may likely occur (Yilmaz et al., 2015; Lee, 2017). Redundancy can occur when work demands exceed employees' coping mechanisms (Karatepe and Olugbade, 2009; Chen et al., 2012). Hence, employees become stressed. Studies have established negative links between stress and task performance (Mann and Cowburn, 2005). Yin $e t$ al. (2017) submit that employees who suffer physical and emotional stress as a result of feeling burnout or feeling frustrated are likely to have reduced task performance.

Task performance is equally affected when employees resort to obtaining leave of absence, voluntary resignation, arbitrary absenteeism and so forth (Mariesa and Rockoff, 2012; Mafukata and Mudau, 2016). These acts are usually done to avoid total depletion of their self-autonomy or self-esteem (Grandey and Sayre, 2019), particularly when they cannot put up anymore with the acting strategies.

\section{Social-economic consequences}

Because the emotions for acting cheery, pleasant or smiling cannot be quantified, both techniques are usually undercompensated (Hülsheger et al., 2015). This is due to the fact that the techniques are intrinsically motivated acts. Grandey et al. (2015) note that employees are faced with interactional injustice through unapologetic customers, and any attempt by employees to engage in emotion deviance (display genuine emotions) might lead to punitive measures, such as job loss, pay cut, reprimand, suspension or dismissal (Hagenauer and Volet, 2014; Yagil, 2015; Richard et al., 2016).

Emotional deviance occurs when expressed emotions clash (or are incongruent) with organizational display rules (Richard and Converse, 2016). It is when employees disregard the rules to express their authentic emotions. This often leads to counter-productive work behaviour (Hunter and Penney, 2014). In most cases, the erring employees bear the brunt (Dahling, 2016). Socially, the ripple effects can cause transferred aggression among peers, colleagues or repercussion at home (Krannitz et al., 2015; Wagner et al., 2014), e.g. workfamily or domestic conflicts (Erdamar and Demirel, 2014; Isa et al., 2018). 


\section{Organizational commitment}

$\mathrm{OC}$ is the "extent to which an individual identifies and is involved with his or her organization and/or is unwilling to leave it" (Greenberg and Baron, 2008, p. 234). Individuals with perceived high $\mathrm{OC}$ takes pride in considering themselves a part of an organization. Hence, it is about employees' attitudes and behaviours, placed on a continuum (Ko et al., 1997; Dixit and Bhati, 2012), towards the organization in which they work.

Meyer and Allen (1991, p. 61) contend that "commitment is a psychological state" experienced within three components model (TCM). These include commitment as a desire (affective), a need (continuance) and an obligation (normative). These components have been widely applied within the last two decades (Garland et al., 2014; Jaros, 2017; Sonar and Paliwal, 2018). Each of the components in the TCM is discussed in the next sub-section.

\section{Affective commitment}

Affective Commitment (AC) is "the strength of a person's desire to work for an organization because he or she agrees with it and wants to do so" (Greenberg and Baron, 2008, p. 236). It is linked to employee's belief in organizations' core values such as the mission and vision statements (Robbins and Judge, 2007). Sonar and Paliwal (2018) say that AC involves a show of willingness to exert effort to remain with the organization. Hence, it is a form of employees' emotional attachment to the organization. Researchers (Meyer and Allen, 1991; van Gelderen and Bik, 2016) consider values like equity in reward distribution, organizational support, delivering quality services, role clarity and decentralization of decision-making as reasons for employees' AC.

\section{Continuance commitment}

Meyer et al. (1993) modelled Continuance commitment (CC) along Becker's (1960) side-bet theory of commitment. Becker (1960, p. 33) notes that commitment is employees' disposition to engage in "consistent lines of activity" as a result of accumulation of "side-bets" that would be lost if the activity is discontinued. Meyer and Allen (1991, p. 64) say side-bet occurs when "something of importance to an individual (e.g. pension) becomes contingent upon continued employment". In this regard, CC can be referred to as "perceived economic value of remaining with an organization compared to leaving it" (Robbins and Judge, 2007, p. 80).

Research equally indicates that CC measures "high sacrifices' and "low alternatives" (Jaros and Culpepper, 2014, p. 70). This means that employees' CC is determined not only by fear of losing side-bets (e.g. incentives and investments) but also by low availability of other jobs (Ko et al., 1997; Powell and Meyer, 2004). Shore et al. (2000) posit that social costs might contribute to employees' side-bets, e.g. friendly co-workers. In essence, $\mathrm{CC}$ may be due to fear of losing benefits or perceived lack of alternative jobs (Dixit and Bhati, 2012; Jaros and Culpepper, 2014). Therefore, employees may continue with an organization because it is perceived too costly to leave.

\section{Normative commitment}

Normative Commitment (NC) deals with the "desires of employees to continue working for an organization because he or she feels the obligations from others to remain" (Greenberg and Baron, 2008, p. 236). The obligation to remain with an organization might be due to ethical or moral reasons (Robbins and Judge, 2007), or due to thoughts on the perception of co-workers (Meyer and Allen, 1991). Employees with this form of mindset put into consideration their perceived responsibility to their organizations.

NC can be likened to a "reasoned-action models of behaviour" (Meyer and Allen, 1991, p. 66), an "indebted obligation" (Jaros, 2007, p. 12), or a form of psychological contract 
PRR

4,1

(Rousseau, 1998), where employees believe that their continued stay with an organization is the right thing to do. For instance, employees whose organization have granted scholarship or training skills may feel it is ethically and morally important to remain with the institution until the expirations of the agreed working terms and conditions.

\section{Hypotheses development}

Findings from previous studies on employees' SA and DA techniques are not consistent. For instance, Lartey et al. (2019) found a negative relationship between SA and job attitudes. But, reported no significant relationship for DA. Lee and Van Vlack's (2017) extended research on teachers' emotions, EL techniques and teachers' efficacy, revealed that SA relates negatively with teachers' efficacy, whereas, DA correlated positively. Chen et al. (2012) show that SA relates negatively with job satisfaction but positively with burnout, whereas DA was positive with job satisfaction but negatively related with burnout. In the latter case, the researchers argued that incessant DA can have some negative after-effects.

Xin et al. (2017) found that SA does not necessarily lead to burnout because the technique can immediately be discarded. Therefore, it has no significant impact on employees' outcomes and attitudes. However, DA can cause burnout because it is prolonged. Garland et al. (2014) argue that when service workers experience burnout, organizational activities can negatively be affected. To buttress this, Prentice (2014) found that emotional exhaustion, depersonalization and lack of accomplishment can make an employee distance himself or herself emotionally or cognitively from work. Prentice (2014) linked these findings to the negative impact of SA and DA on employees' emotional state of being. However, in the study of Lee (2018), only DA was reported to be positive with employees' attitude to work and job satisfaction. The study found no significant relationship with SA.

Based on conservation of resource (COR) theory (Hobfoll, 1989), Van Gelderen (2013, p. 65) assents that SA and DA can "have negative valence". It was argued that employees with low energetic resource level will find it difficult to regulate their emotions, particularly for DA. Studies show that in most situations, employees are prone to spiral resource-loss because the time frame for DA is undetermined (Zapf, 2002; Burić, 2019; Walsh et al., 2019). Kwak et al. (2018) contend that resource-loss often makes employees cynical towards work because it threatens their psychological well-being. This arouses feelings of dissatisfaction and can diminish their OC.

Walsh and Bartikowski (2013) argued that employees' organizational involvement can fluctuate based on emotional experiences. For instance, Grandey et al. (2015) submit that both SA and DA involve suppression of felt emotions. Researchers (Kidwell et al., 2011; Pillay et al., 2019; Yin et al., 2019) assent that suppressing felt emotions for organizational required emotions often contribute to employees' feelings of detachment from the organization. Brotheridge and Lee (2003) note that suppressing emotions can inhibit employees' sense of belongingness, connectedness with colleagues or organizational goals. In essence, both techniques are not free of negative consequences.

In view of the aforementioned, consistent with the assumptions of $A E T$, this study hypothesized as follows:

H1. SA relates negatively with OC.

H2. DA relates negatively with $\mathrm{OC}$.

\section{Methodology}

Study participants

Through a list-based simple random sampling technique, teachers from 30 secondary schools around Peninsular Malaysia were randomly selected. 
A total of 450 teachers were expected to respond to the 27 items questionnaire. The adequacy of the sample size is within the recommended threshold of a minimum of five respondents per item for exploratory factor analysis (EFA) (Hair et al., 2010; Tsang et al., 2017).

\section{Measure (instruments)}

Surface acting and deep acting techniques. Brotheridge and Lee's (2003) ELS was adapted. The scale has 3 items for SA and DA respectively. However, to justify the minimum of four items per construct for confirmatory factor analysis (CFA) (Hair et al., 2010), relevant items were sourced from Näring et al. (2007) D-QEL scale. This brought SA and DA to 5 and 4 items respectively. Items were anchored on a Likert-type scale of $(1=$ "never" to $5=$ "always"). Item example include: "I pretend to have the emotions that I am not actually feelings".

Organizational commitment. (Meyer et al., 1993) TCM was adapted. It was tapped on a five-point Likert scale of ( $1=$ "strongly disagree" to $5=$ "strongly agree"). This study adapted TCM as a second-order construct with three dimensions. They are effectiveness, affective, continuance, and normative commitment. Each dimension has six items. Item example include: "the organization has a great deal of personal meaning for me".

\section{Data collection}

Data was collected electronically. Sekaran (2003, p. 250) posits that through electronic means "more reliable data are likely to result since the respondents can go back and forth, and easily change a response." In addition, electronic means "guaranteed informed consent and data confidentiality" (Antunes et al., 2017 p. 5). Data collection was between May and August 2019.

\section{Statistical analysis}

IBM SPSS 24.0 software was used for demography frequencies and EFA. AMOS 24.0 software was used for CFA data validation and SEM hypotheses testing.

\section{Results}

Response rate

From 450 expected responses, 35 respondents participated in the pilot study instrument adaptation stage. Main study had 415 participants, out of which 389 responses were received. This gave a response rate of 93.74 per cent. "Straight-lining or satisficing" responses were invalidated with respect to Ron et al. (2015, p. 688) recommendations. So, 16 responses were invalidated. In this regard, only 373 valid usable responses were analysed, giving a usable response rate of 89.88 per cent. This high response rate was due to several follow-up measures (e.g. phone calls, emails and visitations). The convenience of responding to an electronic questionnaire also contributed to the high response rate.

Social-demographic characteristics (main study)

Participants are mostly between the years of 30 and $45(\mathrm{M}=2.35 ; \mathrm{SD}=1.02)$. With respect to Table I, 52 (14.0 per cent) men and 167 (44.8 per cent) women have master's and bachelor's degrees, respectively, 122 (32.7 per cent) women have spent over 10 years in the teaching profession, out of which 176 (47.2 per cent) were married. 


\begin{tabular}{|c|c|c|c|c|c|c|c|}
\hline & & & & & & & \\
\hline & \multicolumn{7}{|c|}{ Gender } \\
\hline & \multirow[b]{2}{*}{ Demographic variables } & \multicolumn{2}{|c|}{ Male } & \multicolumn{2}{|c|}{ Female } & \multicolumn{2}{|c|}{ Total } \\
\hline \multirow[b]{2}{*}{68} & & Count & $(\%)$ & Count & $(\%)$ & Count & $(\%)$ \\
\hline & $\begin{array}{l}\text { Age } \\
\text { Below } 30 \\
30-45 \\
46-50 \\
\text { Above } 50\end{array}$ & $\begin{array}{l}21 \\
42 \\
10 \\
24\end{array}$ & $\begin{array}{r}5.6 \\
11.3 \\
2.7 \\
6.4\end{array}$ & $\begin{array}{r}51 \\
133 \\
37 \\
55\end{array}$ & $\begin{array}{c}13.6 \\
35.6 \\
9.91 \\
14.8\end{array}$ & $\begin{array}{r}72 \\
175 \\
47 \\
79\end{array}$ & $\begin{array}{l}19.3 \\
46.9 \\
12.6 \\
21.2\end{array}$ \\
\hline \multirow{4}{*}{$\begin{array}{l}\text { Table I. } \\
\text { Cross-tabulation } \\
\text { social-demographic } \\
\text { characteristics of } \\
\text { respondents }\end{array}$} & $\begin{array}{l}\text { Education } \\
\text { Master } \\
\text { Bachelor } \\
\text { Others }\end{array}$ & $\begin{array}{l}18 \\
30 \\
49\end{array}$ & $\begin{array}{r}4.8 \\
8.0 \\
13.1\end{array}$ & $\begin{array}{r}52 \\
167 \\
57\end{array}$ & $\begin{array}{l}14.0 \\
44.8 \\
15.3\end{array}$ & $\begin{array}{r}70 \\
197 \\
106\end{array}$ & $\begin{array}{l}18.8 \\
52.8 \\
28.4\end{array}$ \\
\hline & $\begin{array}{l}\text { Work experience } \\
\text { Below } 2 \text { years } \\
2-5 \text { years } \\
6-10 \text { years } \\
\text { Above } 10 \text { years }\end{array}$ & $\begin{array}{r}7 \\
30 \\
24 \\
36\end{array}$ & $\begin{array}{l}1.9 \\
8.0 \\
6.4 \\
9.7\end{array}$ & $\begin{array}{r}12 \\
90 \\
52 \\
122\end{array}$ & $\begin{array}{r}3.2 \\
24.2 \\
14.0 \\
32.7\end{array}$ & $\begin{array}{r}19 \\
120 \\
76 \\
158\end{array}$ & $\begin{array}{r}5.1 \\
32.2 \\
20.4 \\
42.4\end{array}$ \\
\hline & $\begin{array}{l}\text { Marital status } \\
\text { Single } \\
\text { Married } \\
\text { Others } \\
\text { Religion }\end{array}$ & $\begin{array}{r}13 \\
78 \\
6 \\
97\end{array}$ & $\begin{array}{r}3.5 \\
20.9 \\
1.6 \\
26.0\end{array}$ & $\begin{array}{r}82 \\
176 \\
18 \\
276\end{array}$ & $\begin{array}{r}22.0 \\
47.2 \\
4.8 \\
74.0\end{array}$ & $\begin{array}{r}95 \\
254 \\
24 \\
373\end{array}$ & $\begin{array}{r}25.5 \\
68.1 \\
6.4 \\
100\end{array}$ \\
\hline & Source: Field survey (2019) & & & & & & \\
\hline
\end{tabular}

The social-demographic table demonstrates an unequal representation of gender as teachers. It can be inferred that there are more female teachers than their male counterpart (see Malaysia Ministry of Education Report - 2018, p. 26)[1].

\section{Questionnaire characteristics}

From Table II, the aggregate average score shows that teachers from time to time practice SA $(M=2.57 ; S D=1.26)$ and periodically use DA $(M=3.16 ; S D=1.12)$. The internal reliability scores for each construct suggested the existence of a strong internal consistency among all questionnaire items. Therefore, each item actually measures what it intends to measure. Values of skewness and kurtosis (not shown here due to space) revealed that most questionnaire items fell within the acceptable value range of $z= \pm 1.96(p<0.05)$ (Pallant, 2007). These outcomes suggest that data are normally distributed.

\section{Psychometric validation report}

Exploratory factor analysis

All constructs were adapted. So, they were subjected to principal component analysis (PCA). Prior to performing PCA, the suitability of data for factor analysis was examined. For

Table II.

Average mean, standard deviations and reliability

\begin{tabular}{lcccc}
\hline Constructs & Items & Mean & SD & Alpha $(\alpha)$ \\
\hline SA & 5 & 2.57 & 1.26 & 0.94 \\
DA & 4 & 3.16 & 1.12 & 0.80 \\
OC & 18 & 3.97 & 0.86 & 0.90
\end{tabular}

Source: SPSS output table (2019) 
instance, observation of correlation matrix revealed the presence of coefficients $(r \geq 0.3)$. KMO was 0.877 and 0.847 for EL techniques and OC, respectively. These values exceeded the recommended value of 0.6 (Kaiser, 1974). Bartlett's Test of Sphericity $(p<0.05)$ reached statistical significance (Bartlett, 1954). Data adequacy was equally proven with items having communalities values above 0.3 recommended threshold (Pallant, 2007). These preliminary outcomes lend credence for data factorability.

In this regard, varimax normalized rotated component matrix retained a two-factor solution (SA and DA) for EL techniques. SA has five items with Alpha $(\alpha)$ value of 0.94 and DA has four items with Alpha $(\alpha)$ value of 0.80 . Rotation maintained a 3-components-18-items solution for OC. They are $\mathrm{AC}(\alpha=0.77), \mathrm{CC}(\alpha=0.84)$ and $\mathrm{NC}(\alpha=0.81)$. Each has six items. The alpha values $(\alpha)$ attached with each construct implies that the factored solution demonstrated acceptable measurement properties (Nunnally, 1978). Cronbach (1951) notes that high alpha values indicate strong reliability. Theoretically, this provides support for further statistical analysis.

\section{Confirmatory factor analysis}

The measurement model was validated through maximum likelihood method (Bentler, 1983) using renowned goodness-of-fit $(\mathrm{GOF})$ indices. Results revealed that $\chi^{2} / d f$ ratio $(467.264 / 263)=$ 1.777, RMSEA (0.046) and CFI (0.956). Results provided evidence of a reasonable and good data-fit model (Marsh and Hocevar, 1985; Browne and Cudeck, 1993).

Further examination of the measurement model for construct validity through convergent validity, discriminate validity, construct reliability (CR) and average variance extracted (AVE) also supported the proposed model. Two items from OC are dropped because of low estimate loadings. So, only 25 items were assessed. Standardized estimate loadings for the 25 items were above 0.5 and $\leq 0.96$. Taken together, all assessment values are within recommended acceptable ranges (Schumacker and Lomax, 2012) (Table III). Hence, construct validity is supported. This provides further support and validity for the proposed model.

\section{Structural equation modelling}

Having established the construct validity, the structural model was assessed toempirically test the study's hypotheses. GOF results are slightly different from the measurement model (Table IV). Still, the structural model has reasonably GOF indices. Its $\chi^{2} / d f$ ratio (560.069/ $265)=2.113$, RMSEA (0.055) and CFI (0.936). All indices fulfilled the recommended thresholds (Hair et al., 2010; Kline, 2011). This implies that the hypothesized structural model represented the sampled population.

In Figure 1, parameters standardized path estimates reveal that SA and $\mathrm{OC}$ relate significantly negatively with each other ( $H 1: \beta=-0.23, p<0.05)$. It also indicates that DA and $\mathrm{OC}$ have significant negative relationship (H2: $\beta=-0.20, p<0.05$ ). These results provide sufficient support to the study's proposed hypotheses. This establishes that $H 1$ and $H 2$ are valid and significant. Therefore, it can be upheld that not only SA leads to negative after-effects, DA can also lead to same.

\section{Discussions}

The study investigated the relationship between SA, DA and OC. Though, there are known benefits embedded in applying SA and DA, such as promoting good customers' experiences (Hofmann and Stokburger-Sauer, 2017), enhancing task accomplishment (Becker and Cropanzano, 2015), encouraging customer retention (Chen et al., 2012), boosting business success (Zou and Dahling, 2017) or promoting organization's good image to the public (Christoforou and Ashforth, 2015), the consequences of the techniques can be demoralizing for teachers. 


\section{PRR}

4,1

SA DA OC

Constructs Items Standardized estimate loadings

70

DA

$\begin{array}{lll} & \text { SA } & \text { EL1 }\end{array}$

EL2 0.96

EL3 0.91

EL4

0.91

EL5 0.76

EL6

EL7

0.68

EL8

0.71

EL9

$\mathrm{AC}$

$\mathrm{OC} 1$

0.74

0.75

OC2

0.79

0.81

OC3

0.75

OC4

0.69

OC5

0.79

OC6

$\begin{array}{ll}\mathrm{CC} & \mathrm{OC} 7\end{array}$

0.72

0.69

OC8

0.79

OC9

0.72

OC10

0.61

OC11

NC OC14

0.74

0.68

OC15

0.75

OC16

0.73

OC18

0.62

AVE

0.925
0.260

CR

0.519

0.811

0.526

0.946

Max. Shared Variance (MSV)

0.290

0.160

Thresholds Remarks

AVE $\geq 0.50 \quad$ Supported

$\mathrm{CR} \geq 0.70 \quad$ Supported

Table III.

CFA validity

Convergent validity

$C R>A V E$

Supported

assessment tests

Discriminant validity

$M S V<A V E$

Supported

CFA

Measurement

\begin{tabular}{lccc} 
GOF & model & Structural model & Thresholds \\
\hline Chi-square $\left(\chi^{2}\right) / d f$ & $467.264 / 263$ & $560.069 / 265$ & Sensitive to size
\end{tabular}

Absolute fit measures

$P$-value

Normed chi-square (CMIN/DF)

Root mean sq. error of appr. (RMSEA)

Incremental fit indices

Comparative fit index (CFI)

Tucker-Lewis Index (TLI)

$\begin{array}{ccc}0.000 & 0.000 & P>0.05 \\ 1.777 & 2.113 & r<5^{*} \\ 0.046 & 0.055 & \leq 0.08^{* *} \\ & & \\ 0.956 & 0.936 & >0.90^{* * * *} \\ 0.950 & 0.928 & >0.90^{* * *}\end{array}$

Source: AMOS Output Table (2019)

Table IV.

Notes: *Ratios not greater than 5 indicate a reasonable fit (Marsh and Hocevar, 1985); **Values of about GOF indices good fit (Bentler, 1983; Jan, 2012; Zainudin, 2014) 


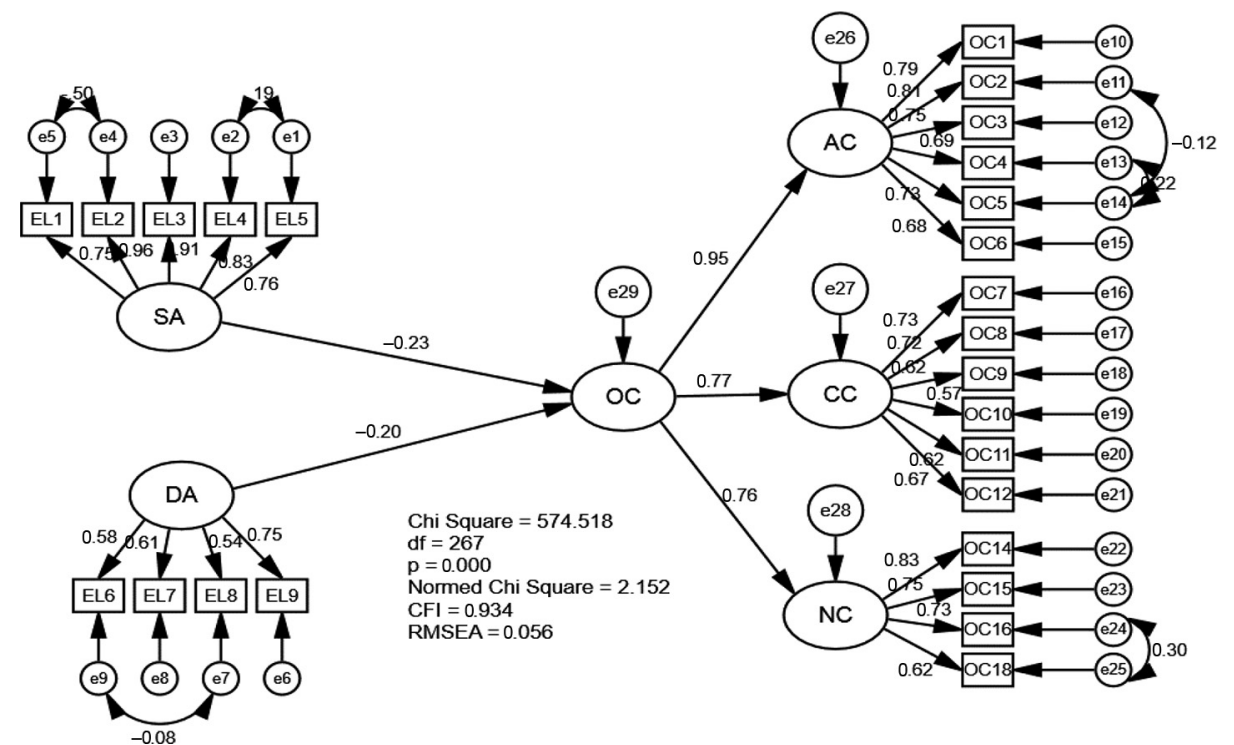

\section{Impact of surface acting and deep acting techniques}

This study's findings are consistent with previous studies. Extant literature documents that prolonged engagement in either SA or DA can cause "pernicious psychological effects" (Ashforth and Humphrey, 1993, p. 89). Meyer et al. (2002) highlight work stressors on employees' health and well-being as one of the negative antecedents of OC. Barber et al. (2011) identifies emotion regulation as a prime cause of employees' stress, particularly when they are emotionally exhausted. This implies that employees will possibly record a low level of OC when stressed emotionally. Cropanzano et al. (2003) discussed that regulating employees' emotions can increase their turnover intention and lower their AC.

In spite of the aforementioned benefits, SA and DA can be "psychologically demanding" (Becker and Cropanzano, 2015, p. 198). Researchers (Kwok, 2011; Dahling, 2016) argue that modulating between felt and expected emotions often come with certain perils to the actors. This was evident through the outcome of this study wherein both SA and DA show significant negative relationship on OC. Seemingly, engaging in SA and DA implies that "emotions are bought on the one hand and sold on the other" (Hochschild, 1983, p. 118). This implies that employees give up control over how the work is done by allowing the organization to set the standard practices on how work is to be carried out. Mostly, this process is not free of emotional setbacks.

The fact remains that emotion is an integral inalienable part of human personality (Kim and Han, 2009). So, employees' reaction or behaviour is sometimes hard to conceal even with SA and DA techniques. The reason is that emotions are "experienced physically as well as mentally" (Houghton et al., 2012, p.222). In this regard, both SA and DA often lead to self-alienation (Hülsheger et al., 2015; Benita et al., 2016), numbness and poor self-esteem (Ashforth and Humphrey, 1993), self-estrangement (Wagner et al., 2014; Krannitz et al., 2015), distributive, procedural and interpersonal injustice (Grandey et al., 2015), burnout (Xin et al., 2017), loss of tacit knowledge or intention to quit (Chen et al., 2012), health-related problems such as heart attack (Mesmer-magnus et al., 2012) and lack of autonomy (Zou and Dahling, 2017).

Inability to internalize expected emotions can lead to emotional experiences like frustration and anxiety. As a result, employees often resort to task avoidance (Garland et al., 
PRR

4,1

2014), arbitrary absenteeism (Karatepe and Choubtarash, 2014), tardiness (Walsh and Bartikowski, 2013), leave of absence or voluntary resignation (Mariesa and Rockoff, 2012; Mafukata and Mudau, 2016) and so forth. When taken together, these occurrences can portend diminishing effects on OC.

\section{Conclusion}

The current study suggests that Malaysian teachers view that SA and DA can hinder their OC. Particularly, when the techniques are used unabated or not mediated. This was evidenced through the outcome of this study. It was discussed that conflict in emotional experiences (i.e. discrepancy between felt emotions and required teaching emotions) often lead to negative consequences such as self-alienation, self-detachment, internal tension and emotional exhaustion. These phenomena can reduce the likelihood of teachers' commitment to their job. To this end, the SA and DA can weaken employees' intrinsic urge for OC.

\section{Implications/contributions}

The study provides insight on the shared problems associated with both SA and DA. Literature studies have been engulfed with debate about whether SA is negatively related to employees' organizational outcomes, DA is positively related to employees' organizational outcomes or there is no significant relationship between these workplace events. In this regard, the study's findings clarified these mixed feelings. Theoretically, this extends emotional labour and organizational behaviour research. The findings also have important policy implications. Because ending SA and DA techniques are "seemingly unrealistic" (Kwak et al., 2018, p. 17), HR managers may possibly come up with strategic policies/programmes to mediate the consequences of the techniques. For instance, organizing family re-treat, counselling session, paid oversea vacation trips and so forth. Lastly, the practical implication of the study's findings is that employees who engage in diverse emotional display are aware of the shared problems associated with both SA and DA. Hence, they can devise self-strategy, like developing spiritual intelligence, to cope with the negative after-effects of the techniques. By so doing, employees can abide with organizational required emotions without hassle.

\section{Limitation and future areas of research}

Firstly, the study is cross-sectional. So, data collection was on a one-time basis. This may have subjected the study's outcomes to common method bias. Future study can collect data on a longitudinal time frame to establish a proper cause-and-effect relationship. Secondly, the study was limited to secondary school teachers. Future study may consider other service employees, or perhaps, other contextual setting to re-confirm this study's outcomes. For instance, university lecturers can be examined. Because this group of employees interacts with young adults, it may be that the intensity of SA and DA required will be seemingly reduced when compared with that required in secondary school teachers that interact with teenagers.

Future study may equally seek for ways to minimize the consequences of SA and DA on employees. This is important because the wellness of employees' emotions can have positive ripple effects on their work performance. Supposedly, when quality attention is given to the heart, it spontaneously anticipates giving quality to the body. Besides, the aim of employees is not only to be rewarded at month-end but also to find meaning and value in workplace activities (Khaliq and Ogunsola, 2011; Feng et al., 2017; Fontaine, 2018; Ogunsola, 2018). In this regard, future study may consider investigating variables like spiritual intelligence to mediate the negative impacts of SA and DA on OC. Certainly, when employees feel good, there is hardly anything that is better at that moment; however, the instance when that feeling is disrupted, it takes a toll on the individual and possibly those around. 
1. Education Planning and Research Division. Private Education Division, Ministry of Education (2018, January 31). Retrieved from: www.moe.gov.my/index.php/menumedia/media-cetak/ penerbitan/terbitan/buku-informasi/1587-quick-facts-2018-malaysia-educational-statistics-1/file (accessed 23 June 2019).

\section{References}

Addison, M. (2017), "Overcoming Arlie hochschild's concepts of the 'real' and 'false' self by drawing on Pierre Bourdieu's concept of habitus”, Emotion, Space and Society, Vol. 23, pp. 9-15, doi: 10.1016/ j.emospa.2017.01.003.

Andrews, M.C., Kacmar, K.M. and Valle, M. (2016), "Surface acting as a mediator between personality and attitudes”, Journal of Managerial Psychology, Vol. 31 No. 8, pp. 1265-1279, doi: 10.1108/JMP-11-2015-0414.

Antunes, R.R., Silva, A.P. and Oliveira, J. (2017), "Spiritual intelligence Self-Assessment inventory: psychometric properties of the Portuguese version of SISRI-24", Journal of Religion, Spirituality and Aging, Vol. 30 No. 1, pp. 12-24, doi: 10.1080/15528030.2017.1324350.

Ashforth, B.E. and Humphrey, R.H. (1993), "Emotional labor in service roles: the influence of identity", Academy of Management Review, Vol. 18 No. 1, pp. 88-115.

Ashkanasy, N.M. and Humphrey, R.H. (2011), "Current emotions research in organizational behavior", Emotion Review, Vol. 3 No. 2, pp. 214-224, doi: 10.1177/1754073910391684.

Barber, L.K., Grawitch, M.J., Carson, R.L. and Tsouloupas, C.N. (2011), "Costs and benefits of supportive versus disciplinary emotion regulation strategies in teachers", Stress and Health, Vol. 27 No. 3, pp. 173-187, doi: 10.1002/smi.1357.

Bartlett, M.S. (1954), "A note on the multiplying factors for various chi square approximations", Journal of the Royal Statistical Society: Series B (Methodological), Vol. 16, pp. 296-298.

Becker, H. (1960), "Notes on the concept of commitment", American Journal of Sociology, Vol. 66 No. 1, pp. 32-40.

Becker, W.J. and Cropanzano, R. (2015), "Chapter 8 display rules and emotional labor within work teams”, Research on Emotion in Organizations, pp. 197-223, doi: 10.1108/S1746-9791(2011)0000007013.

Benita, M., Levkovitz, T. and Roth, G. (2016), "Integrative emotion regulation predicts adolescents' Prosocial behavior through the mediation of empathy", Learning and Instruction, Vol. 50, pp. 1-7, doi: 10.1016/j.learninstruc.2016.11.004.

Bentler, P.M. (1983), "Simultaneous equation sysyems as momnet structure models - With an introduction to latent variable models", Journal of Econometrics, Vol. 22 Nos 1/2, pp. 13-42.

Brotheridge, C.M. and Lee, R.T. (2003), "Development and validation of the hospitality emotional labour scale", Journal of Occupational and Organizational Psychology, Vol. 76 No. 3, pp. 365-379.

Browne, M.W. and Cudeck, R. (1993), "Alternative ways of accessing model Fit”, in Bollen, K.A. and Long, J.S. (Eds), Testing Structural Equation Models, Sage, Newbury Park, CA, pp. 136-162.

Burić, I. (2019), "The role of emotional labor in explaining teachers' enthusiasm and students' outcomes: a multilevel mediational analysis", Learning and Individual Differences, Vol. 70, pp. 12-20, doi: 10.1016/j.lindif.2019.01.002.

Chen, Z., Sun, H., Lam, W., Hu, Q., Huo, Y. and Zhong, J.A. (2012), "Chinese hotel employees in the smiling masks: roles of job satisfaction, burnout, and supervisory support in relationships between emotional labor and performance", The International Journal of Human Resource Management, Vol. 23 No. 4, pp. 826-845.

Christoforou, P.S. and Ashforth, B.E. (2015), "Revisiting the debate on the relationship between display rules and performance: considering the explicitness of display rules", Journal of Applied Psychology, Vol. 100 No. 1, pp. 249-261.

Cronbach, L.J. (1951), "Coefficient alpha and the internal structure of tests", Psychometrika, Vol. 16 No. 3, pp. 297-334. 
PRR

4,1

Cropanzano, R., Rupp, D.E. and Bryne, Z.S. (2003), "The relationship of emotional exhaustion to work attitudes, job performance, and organizational citizenship behaviors", Journal of Applied Psychology, Vol. 88 No. 1, pp. 160-169, doi: 10.1037/0021-9010.88.1.160.

Dahling, J.J. (2016), "Exhausted, mistreated or indifferent? Explaining deviance from emotional display rules at work rules", European Journal of Work and Organizational Psychology, pp. 1-12, doi: 10.1080/1359432X.2016.1229307.

Diefendorff, J.M., Erickson, R.J., Grandey, A.A. and Dahling, J.J. (2011), "Emotional display rules as work unit norms: a multilevel analysis of emotional labor among nurses", Journal of Occupational Health Psychology, Vol. 16 No. 2, pp. 170-186, doi: 10.1037/a0021725.

Dixit, V. and Bhati, M.M. (2012), "A study about employee commitment and its impact on sustained productivity in Indian auto-component industry”, European Journal of Business and Social Sciences, Vol. 1 No. 6, pp. 34-51.

Dunbar, M. and Baker, W.D. (2014), "Teaching as emotional labor: preparing to interact with all students", Language Arts Journal of Michigan, Vol. 30 No. 1.

Erdamar, G. and Demirel, H. (2014), "Investigation of work-family, family-work conflict of the teachers", Procedia - Social and Behavioral Sciences, Vol. 116, pp. 4919-4924, doi: 10.1016/j.sbspro.2014.01.1050.

Feng, M., Xiong, X. and Li, J. (2017), "Spiritual intelligence scale-Chinese form: construction and initial validation”, Current Psychology, Vol. 1, pp. 1-10, doi: 10.1007/s12144-017-9678-5.

Fontaine, R. (2018), "Developing spiritual intelligence: some new evidence", International Journal of Islamic Management and Business, Vol. 7 No. 1, pp. 95-107.

Gökyer, N. (2018), "Organizational commitment of high school teachers”, Journal of Education and Training Studies, Vol. 6 No. 3a, pp. 115-125, doi: 10.11114/jets.v6i3a.3165.

Grandey, A.A. and Sayre, G.M. (2019), "Emotional labor: regulating emotions for a wage", Current Directions in Psychological Science, pp. 1-7, doi: 10.1177/0963721418812771.

Grandey, A.A., Diefendorff, J.M. and Rupp, D.E. (2013), Emotional Labor in the 21 st Century Diverse Perspectives, Routledge, New York, NY.

Grandey, A.A., Rupp, D.E. and Brice, W. (2015), "Emotional labor threatens decent work: a proposal to eradicate emotional display rules", Journal of Organizational Behavior, Vol. 36 No. 6, pp. 770-785, doi: $10.1002 /$ job.

Greenberg, J. and Baron, R. (2008), Behavior in Organizations, 9th ed., Prentice Hall, NJ.

Gross, J.J. (2002), “Emotion regulation: affective, cognitive, and social consequences”, Psychophysiology, Vol. 39 No. 3, pp. 281-291.

Hagenauer, G. and Volet, S.E. (2014), “I don’t hide my feelings, even though I try to’: insight into teacher educator emotion display", The Australian Educational Researcher, Vol. 41 No. 3, pp. 261-281. doi: 10.1007/s13384-013-0129-5.

Hair, J.F., Jr, Black, W.C., Babin, B.J. and Anderson, R.E. (2010), Multivariate Data Analysis, 7th ed., Prentice Hall, NJ.

Hobfoll, S.E. (1989), "Conservation of resources: a new attempt at conceptualizing stress", American Psychologist, Vol. 44 No. 3, pp. 513-524.

Hochschild, A.R. (1983), The Managed Heart: Commercialization of Human Feeling, University of California Press, Barkeley, CA.

Hofmann, V. and Stokburger-Sauer, N.E. (2017), "The impact of emotional labor on employees' worklife balance perception and commitment: a study in the hospitality industry", International Journal of Hospitality Management, Vol. 65, pp. 47-58, doi: 10.1016/j.ijhm.2017.06.003.

Houghton, J.D., Wu, J., Godwin, J.L., Neck, C.P. and Manz, C.C. (2012), "Effective stress management: a model of emotional intelligence, self-leadership and student stress coping", Journal of Management Education, Vol. 36 No. 2, pp. 220-238, doi: 10.1177/1052562911430205.

Hülsheger, U.R., Lang, J.W.B., Schewe, A.F. and Zijlstra, F.R.H. (2015), "When regulating emotions at work pays off: a diary and an intervention study on emotion regulation and customer tips in service jobs",Journal of Applied Psychology, Vol. 100 No. 2, pp. 263-277. 
Hunter, E.M. and Penney, L.M. (2014), “The waiter spit in my soup! antecedents of customer-directed counterproductive work behavior", Human Performance, Vol. 27 No. 3, pp. 262-281, doi: 10.1080/ 08959285.2014.913595.

Huys, Q.J.M. and Renz, D. (2017), "A formal valuation framework for emotions and their control”, Biological Psychiatry, Vol. 82 No. 6, pp. 413-420, doi: 10.1016/j.biopsych.2017.07.003.

Indregard, A.R., Knardahl, S. and Nielsen, M.B. (2018), "Emotional dissonance, mental health complaints, and sickness absence among health- and social workers. the moderating role of selfefficacy", Frontiers in Psychology, Vol. 9 No. 592, pp. 1-9, doi: 10.3389/fpsyg.2018.00592.

Isa, N.M., Kaur, H., Singh, A.P.L. and Hashim, R. (2018), "Job stress, work-to-family conflict and social support in the education industry", Journal of Administrative Science, Vol. 15 No. 3, pp. 1-17.

Jan, M.T. (2012), "The impact of customer relationship management related critical success factors on customer satisfaction: an empirical study of the banks in Malaysia”, Unpublished Doctoral thesis, International Islamic University Malaysia.

Jaros, S. (2007), "Meyer and Allen model of organizational commitment: measurement issues", The Icfai Journal of Organizational Behavior, Vol. VINo. 4, pp. 7-26.

Jaros, S. (2017), “A critique of normative commitment in management research”, Management Research Review, Vol. 40 No. 5, pp. 1-41, doi: 10.1108/MRR-08-2016-0200.

Jaros, S. and Culpepper, R.A. (2014), "An analysis of Meyer and Allen's continuance commitment construct", Journal of Management and Organization, Vol. 20 No. 1, pp. 79-99, doi: 10.1017/jmo.2014.21.

Kaiser, H.F. (1974), "An index of factorial simplicity”, Psychometrika, Vol. 39 No. 1, pp. 31-36.

Karatepe, O.M. and Choubtarash, H. (2014), "The effects of perceived crowding, emotional dissonance and emotional exhaustion on critical job outcomes: a study of ground staff in the airline industry", Journal of Air Transport Management, Vol. 40, pp. 182-191, doi: 10.1016/j.jairtraman.2014.07.006.

Karatepe, O.M. and Olugbade, O.A. (2009), "The effects of job and personal resources on hotel employees 'work engagement”, International Journal of Hospitality Management, Vol. 28 No. 4, pp. 504-512, doi: 10.1016/j.ijhm.2009.02.003.

Khaliq, A. and Ogunsola, O.K. (2011), "An empirical assessment of Islamic leadership principles", International Journal of Commerce and Management, Vol. 21 No. 3, pp. 291-318, doi: 10.1108/ 10569211111165325.

Kidwell, B., Hardesty, D.M., Murtha, B.R. and Sheng, S. (2011), "Emotional intelligence in marketing", Journal of Marketing, Vol. 75 No. 1, pp. 78-95, doi: 10.1509/jm.75.1.78.

Kim, M.J. and Han, S.Y. (2009), "Relationship between emotional labor consequences and employees' coping strategy", Asia Pacific Journal of Tourism Research, Vol. 14 No. 3, pp. 225-239, doi: $10.1080 / 10941660903023929$.

Kinman, G., Wray, S. and Strange, C. (2011), "Emotional labour, burnout and job satisfaction in UK teachers: the role of workplace social support", Educational Psychology, Vol. 31 No. 7, pp. 843-856, doi: 10.1080/01443410.2011.608650.

Kline, R.B. (2011), Principles and Practice of Structural Equation Modeling, 3rd ed., The Guildford Press, New York, NY.

Ko, J., Price, J.L. and Mueller, C.W. (1997), "Assessment of Meyer and Allen's three-component model of organizational commitment in South Korea”, Journal of Applied Psychology, Vol. 82 No. 6, pp. 961-973.

Krannitz, M.A., Grandey, A.A., Liu, S. and Almeida, D.A. (2015), "Workplace surface acting and marital partner discontent: anxiety and exhaustion spillover mechanisms", Journal of Occupational Health Psychology, Vol. 20 No. 3, pp. 314-325.

Kulshrestha, S. and Singhal, T.K. (2017), "Impact of spiritual intelligence on performance and job satisfaction: a study on school teachers", International Journal of Human Resource and Industrial Research, Vol. 4 No. 2, pp. 1-6, doi: 10.5281/zenodo.343742.

Kwak, H., Mcneeley, S. and Kim, S. (2018), "Emotional labor, role characteristics, and police officer burnout in South Korea: the mediating effect of emotional dissonance", Police Quarterly, pp. 1-27, doi: 10.1177/ 1098611118757230. 
PRR

4,1

Kwok, K.T. (2011), "Emotional labor of teaching”, Educational Research, Vol. 2 No. 8, pp. 1312-1316.

Lam, W. and Chen, Z. (2012), "When I put on my service mask: determinants and outcomes of emotional labor among hotel service providers according to affective event theory", International Journal of Hospitality Management, Vol. 31 No. 1, pp. 3-11, doi: 10.1016/j.ijhm.2011.04.009.

Lartey, K.J.S., Kwesi, A. and Joseph, O. (2019), “The moderating effect of perceived organizational support in the relationship between emotional labour and job attitudes: a study among health professionals", Nursing Open, pp. 1-8, doi: 10.1002/nop2.295.

Lee, H.J. (2018), "Relation between display rules and emotive behavior strategies and its outcomes among South Korean public service employees", Public Performance and Management Review, pp. 1-22, doi: $10.1080 / 15309576.2018 .1464479$.

Lee, Y.H. (2017), "Emotional labor, teacher burnout, and turnover intention in high-school physical education teaching", European Physical Education, pp. 1-18, doi: 10.1177/1356336X17719559.

Lee, M. and Van Vlack, S. (2017), "Teachers' emotional labour, discrete emotions, and classroom management self-efficacy", Educational Psychology, Vol. 3410, pp. 1-18, doi: 10.1080/ 01443410.2017.1399199.

Letendre, G.K. and Wiseman, A.W. (2015), "Introduction: the challenges of teacher effectiveness and quality worldwide", Promoting and Sustaining a Quality Teacher Workforce, Vol. 27, pp. 1-38.

Mafukata, M.A. and Mudau, A.V. (2016), "Exploring teacher mass resignation and early retirement from public schools", Dirasat, Human and Social Sciences, Vol. 43, pp. 2243-2255.

Mann, S. and Cowburn, J. (2005), "Emotional labour and stress within mental health nursing", Journal of Psychiatric and Mental Health Nursing, Vol. 12 No. 2, pp. 154-162, doi: 10.1111/j.13652850.2004.00807.x.

Mariesa, H.A. and Rockoff, J.E. (2012), "Worker absence and productivity: evidence from teaching", Journal of Labor Economics, Vol. 30 No. 4, pp. 749-782.

Marsh, H.W. and Hocevar, D. (1985), "Application of confirmatory factor analysis to the study of selfconcept: first- and higher order factor models and their invariance across groups", Psychological Bulletin, Vol. 97 No. 3, pp. 562-582.

Mazer, J.P., McKenna-Buchanan, T.P., Quinlan, M.M. and Titsworth, S. (2014), "The dark side of emotion in the classroom: emotional processes as mediators of teacher communication behaviors and student negative emotions", Communication Education, Vol. 63 No. 3, pp. 149-168, doi: 10.1080/03634523.2014.904047.

Mesmer-Magnus, J.R., Dechurch, L.A. and Wax, A. (2012), "Moving emotional labour beyond surface and deep acting: a discordance-congruence perspective", Organizational Psychology Review, Vol. 2 No. 1, pp. 6-32, doi: 10.1177/2041386611417746.

Meyer, J.P. and Allen, N.J. (1991), "A three-component model conceptualization of organizational commitment”, Human Resource Management Review, Vol. 1 No. 1, pp. 61-89, doi: 10.1016/10534822(91)90011-Z.

Meyer, J.P., Allen, N.J. and Smith, C.A. (1993), "Commitment to organizations and occupations: extension and test of a three-component conceptualization", Journal of Applied Psychology, Vol. 78 No. 4, pp. 538-551, doi: 10.1037/0021-9010.78.4.538.

Meyer, J.P., Stanley, D.J., Herscovitch, L. and Topolnytsky, L. (2002), "Affective, continuance and normative commitment to the organization: a Meta-analysis of antecedents, correlates and consequences", Journal of Vocational Behavior, Vol. 61 No. 1, pp. 20-52, doi: 10.1006/ jvbe.2001.1842.

Mishra, S.K. and Kumar, K.K. (2016), "Minimizing the cost of emotional dissonance at work: a multisample analysis", Management Decision, Vol. 54 No. 4, pp. 778-795, doi: 10.1108/MD-06-2015-0222.

Näring, G., Briët, M. and Brouwers, A. (2007), "Validation of the Dutch questionnaire on emotional labour (D-QEL) in nurses and teachers”, Psychosocial Resources in Human Services Work, pp. 135-145.

Nunnally, J.C. (1978), Psychometric Theory, McGraw-Hill, New York. 
Ogunsola, K.O. (2018), "Servant leadership: developing an Islamic performance appraisal instrument for Muslim managers", Malaysian Management Review, Vol. 53 No. 1, pp. 55-76.

Pallant, J. (2007), SPSS Survival Manual: A Step-by-Step Guide to Data Analysis Using SPSS for Windows (Version 15), 3rd ed., Allen and Unwin, Crows Nest.

Pillay, R., Flotman, A.-P. and Mitonga-Monga, J. (2019), "Emotional labour among women leaders within the South African consulting industry: a hermeneutic phenomenological inquiry", Southern African Business Review, Vol. 23, pp. 1-23, doi: 10.25159/1998-8125/4280.

Powell, D.M. and Meyer, J.P. (2004), "Side-bet theory and the three-component model of organizational commitment", Journal of Vocational Behavior, Vol. 65 No. 1, pp. 157-177.

Prentice, C. (2014), "Emotional labour and its consequences: the moderating effect of emotional intelligence", Research on Emotion in Organizations, Vol. 9, pp. 187-201, doi: 10.1108/S1746-9791(2013)9.

Rafaeli, A. and Sutton, R.I. (1987), "Expression of emotion as part of the work role", The Academy of Management Review, Vol. 12 No. 1, pp. 23-37.

Richard, E.M. and Converse, P.D. (2016), "An examination of within-person variance in contextual display rules and deviation from display rules", European Journal of Work and Organizational Psychology, Vol. 25 No. 3, pp. 412-429, doi: 10.1080/1359432X.2015.1102133.

Richard, E.M., Bupp, C.P. and Alzaidalsharief, R.G. (2016), "Supervisor empathy moderates the negative effects of customer injustice", Emotions and Organizational Governance, Vol. 12, pp. 117-140, doi: 10.1108/S1746-979120160000012004.

Robbins, S.P. and Judge, T.A. (2007), Organizational Behaviour, 12th ed., Prentice Hall, Pearson, NJ.

Ron, D.H., Honghu, L. and Arie, K. (2015), "Use of internet panels to conduct surveys", Behavioral Research Methods, Vol. 47, pp. 685-690, doi: 10.3758/s13428-015-0617-9.

Rousseau, D.M. (1998), "The 'problem' of the psychological contract considered", Journal of Organizational Behavior, Vol. 19, pp. 665-671.

Schirmer, A. and Adolphs, R. (2017), "Emotion perception from face, voice, and touch: comparisons and convergence", Trends in Cognitive Sciences, Vol. 21 No. 3, pp. 216-228, doi: 10.1016/j.tics.2017.01.001.

Schumacker, R.E. and Lomax, R.G. (2012), A Beginner's Guide to Structural Equation Modeling, 3rd ed., Taylor and Francis, London.

Sekaran, U. (2003), Research Methods for Business: A Skill Building Approach, 4th ed., John Wiley and Sons, Hoboken, New Jersey.

Shore, L.M., Tetrick, L.E., Shore, T.H. and Barksdale, K. (2000), "Construct validity of measures of Becker 's side bet theory”, Journal of Vocational Behavior, Vol. 444, pp. 428-444, doi: 10.1006/jvbe.1999.1749.

Sonar, P. and Paliwal, M. (2018), "The effect of emotional labour on organizational commitment among call Centre customer service representatives", International Joumal of Management, Vol. 9 No. 2, pp. 93-102.

Trigwell, K. (2012), "Relations between teachers' emotions in teaching and their approaches to teaching in higher education”, Instructional Science, Vol. 40 No. 3, pp. 607-621, doi: 10.1007/s11251-011-9192-3.

Tsang, S., Royse, C.F. and Terkawi, A.S. (2017), "Guidelines for developing, translating, and validating a questionnaire in perioperative and pain medicine”, Saudi Jounal of Anaesthesia, Vol. 11 No. 1, pp. 1-15, doi: 10.4103/sja.SJA_203_17.

Van Gelderen, B.R. (2013), At the Heart of Policing Emotional Labor among Police Officers, Erasmus University Rotterdam, available at: hdl.handle.net/1765/40298.

van Gelderen, B.R. and Bik, L.W. (2016), "Affective organizational commitment, work engagement and service performance among police officers", Policing: An International Journal of Police Strategies and Management, Vol. 39 No. 1, pp. 206-221, doi: 10.1108/PIJPSM-10-2015-0123.

Verhoef, H. and Terblanche, L. (2015), "The effect of dissolved workplace romances on the psychosocial functioning and productivity of the employees involved", Social Work/Maatskaplike Werk, Vol. 51 No. 1, pp. 287-310.

Wagner, D.T., Barnes, C.M. and Scott, B.A. (2014), "Driving it home: how workplace emotional labor harms employee home life", Personnel Psychology, Vol. 67 No. 2, pp. 487-516, doi: 10.1111/peps.12044. 
PRR

4,1

Walsh, G., Yang, Z., Dahling, J., Schaarschmidt, M. and Takahashi, I. (2019), "Effects of service employees "negative personality traits on emotional labour and job satisfaction evidence from two countries", Management Decision, pp. 1-19, doi: 10.1108/MD-11-2018-1206.

Walsh, G. and Bartikowski, B. (2013), "Employee emotional labour and quitting intentions: moderating effects of gender and age", European Journal of Marketing, Vol. 47 No. 8, pp. 1213-1237, doi: 10.1108/03090561311324291.

Wegge, J., Dick, R.V., Fisher, G.K., West, M.A. and Dawson, J.F. (2006), "A test of basic assumptions of affective events theory (AET) in call entre work", British Journal of Management, Vol. 17 No. 3, pp. 237-254, doi: 10.1111/j.1467-8551.2006.00489.x.

Weiss, H.M. and Cropanzano, R. (1996), "Affective events theory: a theoretical discussion of the structure, causes and consequences of affective expereinces at work", Research in Organizational Bahavior, Vol. 18, pp. 1-74.

Xin, W., Tong, L. and Yiwen, C. (2017), "Influence of emotional labor on organizational commitment in government logistics personnel: the mediating effect of job burnout and the moderating effect of perceived organizational support", IEEE 19th International Conference on e-Health Networking, Applications and Services (Heathcom).

Yagil, D. (2015), "Display rules for kindness: outcomes of suppressing benevolent emotions", Motivation and Emotion, Vol. 39 No. 1, pp. 156-166, doi: 10.1007/s11031-014-9418-1.

Yilmaz, K., Altinkurt, Y., Guner, M. and Şen, B. (2015), "The relationship between teachers' emotional labor and burnout level", Eurasian Journal of Educational Research, No. 59, pp. 75-90.

Yin, H., Huang, S. and Chen, G. (2019), "The relationships between teachers' emotional labor and their burnout and satisfaction: a Meta-analytic review", Educational Research Review, Vol. 28, p. 100283, doi: 10.1016/j.edurev.2019.100283.

Yin, H., Huang, S. and Lee, J.C.K. (2017), "Choose your strategy wisely: examining the relationships between emotional labor in teaching and teacher efficacy in Hong Kong primary schools", Teaching and Teacher Education, Vol. 66, pp. 127-136, doi: 10.1016/j.tate.2017.04.006.

Zainudin, A. (2014), A Handbook on SEM for Academicians and Practitioners, The step by step practical guides for the beginners, MPWS Rich Resources, Selangor.

Zapf, D. (2002), "Emotion work and psychological well-being: a review of the literature and some conceptual considerations", Human Resource Management Review, Vol. 12 No. 2, pp. 237-268.

Zembylas, M. (2003), “Caring for teachers emotion: reflections on teacher self-development”, Studies in Philosophy and Education, Vol. 22 No. 2, pp. 103-125.

Zou, W. and Dahling, J. (2017), "Workplace spirituality buffers the effects of emotional labour on employee well-being”, European Journal of Work and Organizational Psychology, pp. 1-10, doi: 10.1080/1359432X.2017.1358164.

\section{Further reading}

Ashkanasy, N.M., Härtel, C.E.J. and Daus, C.S. (2002), "Diversity and emotion: the new frontiers in organizational behavior research", Journal of Management, Vol. 28 No. 3, pp. 307-338.

Byrne, B.M. (2010), Structural Equation Modeling with AMOS: Basic Concepts, Applications and Programming, Taylor and Francis Group LLC, New York, NY.

Chau, S.L., Dahling, J.J., Levy, P.E. and Diefendorff, J.M. (2009), “A predictive study of emotional labor and turnover”, Journal of Organizational Behavior, Vol. 30 No. 8, pp. 1151-1163, doi: 10.1002/job.

Dawley, D.D., Stephens, R.D. and Stephens, D.B. (2005), "Dimensionality of organizational commitment in volunteer workers: chamber of commerce board members and role fulfillment", Journal of Vocational Behavior, Vol. 67 No. 3, pp. 511-525, doi: 10.1016/j.jvb.2004.09.001.

Fisher, C.D. (2002), “Antecedents and consequences of real-time affective reactions at work”, Motivation and Emotion, Vol. 26 No. 1, pp. 3-30. 
Frost, M.H., Reeve, B.B., Liepa, A.M., Stauffer, J.W., Hays, R.D. and Mayo, F.P. (2007), "What is sufficient evidence for the reliability and validity of patient-reported outcome measures?", Value in Health, Vol. 10, pp. 94-105.

Garland, B., Lambert, E.G., Hogan, N.L., Kim, B. and Kelley, T. (2014), "The relationship of affective and continuance organizational commitment with correctional staff occupational burnout: a partial replication and expansion study", Criminal Justice and Behavior, Vol. 41 No. 10, p. 1161, doi: $10.1177 / 0093854814539683$.

Grandey, A.A., Tam, A.P. and Brauburger, A.L. (2002), "Affective states and traits in the workplace: diary and survey data from young workers", Motivation and Emotion, Vol. 26 No. 1, pp. 31-55.

Guillemin, F., Bombardier, C. and Beaton, D. (1993), "Cross-cultural adaptation of health-related quality of life measures: literature review and proposed guidelines", Journal of Clinical Epidemiology, Vol. 46 No. 12, pp. 1417-1432.

Lambert, E.G., Kim, B., Hogan, N.L., Kelley, T.M. and Garland, B. (2014), "Why I am here matters: the effects of continuance and affective commitment on the organizational citizenship of private prison staff", Security Journal, pp. 1-16, doi: 10.1057/sj.2014.29.

Lee, J.J., Ok, C.M. and Hwang, J. (2016), “An emotional labor perspective on the relationship between customer orientation and job satisfaction”, International Journal of Hospitality Management, Vol. 54, pp. 139-150, doi: 10.1016/j.ijhm.2016.01.008.

Ling, C.S. (2017), "When teachers who punish are punished, march", available at: www.nst.com.my/ news/2017/03/219611/when-teachers-who-punish-are-punished (accessed 19 September 2018).

Liu, J. and Cho, S. (2018), "Interaction effect of display rules and emotional intelligence on hotel managers' and non-mangers' work engagement", International Journal of Contemporary Hospitality Management, Vol. 30 No. 3, pp. 1903-1919, doi: 10.1108/MRR-09-2015-0216.

Mann, S. (1997), "Emotional labour in organizations", Leadership and Organization Development Journal, Vol. 18 No. 1, pp. 4-12, doi: 10.1108/01437739710156231.

Pugliesi, K. (1999), "The consequences of emotional labor: effects on work stress, job satisfaction and well-being", Motivation and Emotion, Vol. 23 No. 2, pp. 125-154, doi: 10.1023/A:1021329112679.

Solomon, R.C. (2002), "Back to basics: on the very idea of "basic emotions", Journal for the Theory of Social Behaviour, Vol. 32 No. 2, pp. 115-144.

Tabachnick, B.G. and Fidell, L.S. (2007), Using Multivariate Statistics, 5th ed., Pearson Education, Boston.

Vaughan, F. (2002), "What is spiritual intelligence?", Journal of Humanistic Psychology, Vol. 42 No. 2, pp. 16-33, doi: 10.1177/0022167802422003.

Wang, M., Han, Y. and Su, Y. (2017), "Social contagion or strategic choice?: The nterpersonal effects of emotions during Chinese negotiations", Chinese Management Studies, Vol. 11 No. 3, pp. 463-478, doi: 10.1108/CMS-05-2017-0122.

Weiss, H.M. and Beal, D.J. (2005), "Reflections on affective events theory", Research on Emotion in Organizations, Vol. 1, pp. 1-21.

Yin, H. (2015), "The effect of teachers' emotional labour on teaching satisfaction: moderation of emotional intelligence", Teachers and Teaching: Theory and Practice, pp. 1-22, doi: 10.1080/ 13540602.2014.995482.

\section{Corresponding author}

Kazeem Olanrewaju Ogunsola can be contacted at: qmasjid@yahoo.com

For instructions on how to order reprints of this article, please visit our website:

www.emeraldgrouppublishing.com/licensing/reprints.htm

Or contact us for further details: permissions@emeraldinsight.com 